\title{
MODEL ALUR PELAYANAN PEMERIKSAAN RADIOLOGI ERA PANDEMI COVID-19 DI RUMAH SAKIT MAYAPADA JAKARTA SELATAN
}

\author{
Ziko Pratama \\ Universitas Muhammadiyah Prof. Dr. Hamka \\ Jakarta, Indonesia \\ pratamazico14@yahoo.com
}

\author{
Sri Rahayu \\ Universitas Muhammadiyah Prof. Dr. Hamka \\ Jakarta, Indonesia
}

\begin{abstract}
Abstrak
Awal 2020, dunia dikejutkan oleh penemuan kasus pneumonia misterius di Wuhan, Provinsi Hubei, China. Per 11 Februari 2020, WHO menamakan penyakit ini sebagai Coronavirus Disease 2019 (Covid-19) dan ditetapkan sebagai pandemic pada 11 Maret 2020. Penyakit ini disebabkan oleh Servere AcuteRespiratory Syndrome Coronavirus-2 (SARS-CoV-2) jenis Coronavirus baru yang tidak pernah teridentifikasi sebelumnya pada manusia. Situasi ini terdampak pada berbagai aspek kesehatan, termasuk pada aspek pembangunan kesehatan yaitu terhambatnya pelaksanaan pelayanan kesehatan di Indonesia. Tujuan penelitian ini untuk mengidentifikasi alur pelayanan pemeriksaan radiologi pada saat protokol Covid-19 di rumah sakit Mayapada Jakarta Selatan. Desain penelitian ini kualitatif deskriptif dengan pendekatan telaah dokumen berupa hasil swab serta menggunakan alat CT-Scan 128 Slice. Subjek penelitian adalah pasien perempuan dewasa yang melakukan pemeriksaan CT-Scan 128 Slice di Rumah Sakit Mayapada pada Maret 2021. Data yang dikumpulkan berupa hasil gambaran CT-Scan pada kasus pasien positif Covid-19. Hasil penelitian ini menunjukkan gambaran CT-Scan thorax cukup jelas dan dapat mengidentifikasi alur pelayanan pemeriksaan radiologi pada protokol Covid-19 di Rumah Sakit Mayapada Jakarta Selatan.
\end{abstract}

Kata Kunci: alur pelayanan radiologi, pelayanan Covid-19, pemeriksaan radiologi

\section{PENDAHULUAN}

Menurut WHO (World Health Organization), rumah sakit adalah bagian integral dari suatu organisasi sosial dan kesehatan dengan fungsi menyediakan pelayanan paripurna (komprehensif), penyembuhan penyakit (kuratif) dan pencegahan penyakit (preventif) kepada masyarakat. Rumah sakit juga merupakan pusat penelitian bagi tenaga kesehatan dan pusat penelitian medik. Pelayanan di bidang kesehatan merupakan salah satu bentuk pelayanan yang paling banyak dibutuhkan masyarakat. Salah satu sarana pelayanan kesehatan yang mempunyai peran sangat penting lainnya dalam memberikan pelayanan kesehatan kepada masyarakat adalah rumah sakit. Pelayanan kesehatan yang dimaksud tentunya pelayanan yang cepat, tepat, murah dan ramah, karena dari itu pihak rumah sakit dituntut selalu menjaga kepercayaan konsumen secara cermat dengan memperhatikan kebutuhan konsumen sebagai upaya untuk memenuhi keinginan dan harapan atas pelayanan yang diberikan.

Unit Radiologi di rumah sakit merupakan hal yang wajib di sediakan, karena unit radiologi di rumah sakit mempunyai bagian yang sangat penting dalam mengayomi pelayanan radioterapi dan pelayanan radio diagnostik. Unit radiologi juga wajib memperhatikan efek radiasi tersebut kepada pasien di rumah sakit. Semua ini bisa diterapkan dalam rumah sakit apabila telah sesuai dengan petunjuk dan standar pengolahan unit radiologi. Dengan memberikan pelayanan radiologi yang efektif, efisien 
dan bermutu sesuai dengan kebutuhan yang ada di masyarakat baik yang ada di rumah sakit maupun yang berada di luar rumah sakit. Untuk mendapatkan hal tersebut sangat memerlukan manajemen tim yang bermutu untuk memberikan pelayanan prima, tentunya didukung dengan sarana dan ruangan yang nyaman serta aman akan memengaruhi suksesnya tim radiologi dalam memberikan pelayanan di rumah sakit.

Awal 2020, dunia dikejutkan oleh penemuan kasus pneumonia misterius di Wuhan, Provinsi Hubei, China. Per 11 Februari 2020, WHO menamakan penyakit ini sebagai Coronavirus Disease 2019 (Covid-19) dan ditetapkan sebagai pandemik pada 11 Maret 2020. Penyakit ini disebabkan oleh Servere AcuteRespiratory Syndrome Coronavirus-2 (SARS-CoV-2) jenis korona virus baru yang tidak pernah teridentifikasi sebelumnya pada manusia. Situasi ini terdampak pada berbagai aspek kesehatan, termasuk pada aspek pembangunan kesehatan yaitu terhambatnya pelaksanaan pelayanan kesehatan di Indonesia. Pada pelayanan kesehatan di bagian radiologi juga terkena dampak akibat Covid-19 tersebut di antaranya ketidakseragaman fasilitas dan sumber daya manusia, koordinasi terpadu dalam melakukan berbagai pemeriksaan radiologi juga masih jadi tantangan.

Pada alur pelayanan radiologi sebelumnya ada terdapat beberapa masalah yang dirasa harus ditinjau ulang yang di dirasa tidak cocok apabila digunakan untuk alur pasien Covid-19 misalnya ketidaktepatan hasil radiologi, jam operasional pada pelayanan Covid, waktu tunggu lama, dan sebagainya di RS Mayapada oleh karena itu dibutuhkan model alur pelayanan radiologi pada era Covid 19.

Penulis mendeskripsikan bagaimana alur pemeriksaan radiologi pada saat protokol Covid-19 di rumah sakit mayapada Jakarta selatan. Penelitian ini bersifat kualitatif deskriptif yang dilakukan secara observasional pada April 2021 dan telaah dokumen yaitu lembaran swab dan hasil telaah dokumen CTScan di unit radiologi rumah sakit Mayapada Jakarta selatan.

\section{METODE}

Penelitian ini bersifat kualitatif deskriptif yang dilakukan secara observasional menggunakan telaah dokumen yaitu lembaran swab dan wawancara dengan kepala unit radiologi rumah sakit mayapada Jakarta selatan. Populasi penelitian ini adalah pasien laki-laki dewasa yang melakukan pemeriksaan radiologi di Rumah Sakit Mayapada pada bulan April 2021. Data yang dilampirkan berupa hasil swab pasien dan wawancara kepada kepala unit terkait alur prosedur pemeriksaan radiologi tersebut. Alat dan bahan yang digunakan pada penelitian ini yaitu alat Computed Tomography (CTScan) 128 Slice sebagai alat penunjang medis dalam melakukan pemeriksaan radiologi dan juga Thermometer Gun sebagai Scanning awal dalam pemeriksaan tersebut, serta compact disk (CD ) untuk penyimpanan data penelitian. Sebelum pemeriksaan dimulai, pasien diberikan penjelasan mengenai persiapan apa saja yang harus disiapkan sebelum dimulainya pemeriksaan agar pasien kooperatif saat pemeriksaan CT-Scan dilakukan.

\section{HASIL DAN PEMBAHASAN}

\section{Hasil}

Berdasarkan penelitian yang dilakukan dengan prosedur pemeriksaan radiologi pada saat sebelum terjadi pandemi Covid-19 yang ditunjukkan pada gambar 1 pada berikut. 


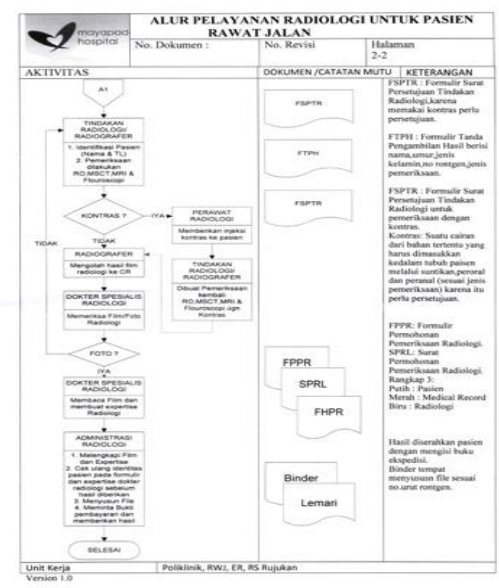

Prosedur alur lama lembar 1

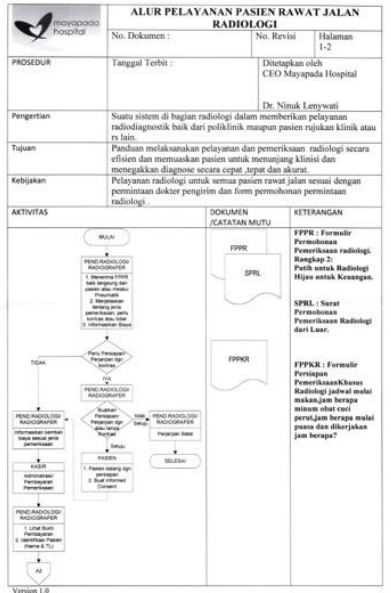

Prosedur alur lama lembar 2

Gambar 1. Prosedur pemeriksaan radiologi pada saat sebelum terjadi pandemi Covid-19

Dari gambar tersebut dapat diuraikan bahwa pada saat pasien menerima formulir pendaftaran radiologi bisa langsung datang ke instalasi tersebut atau bisa menghubungi melalui nomor extension yang sudah di tetapkan oleh pihak rumah sakit, setelah petugas radiologi menjelaskan jenis pemeriksaan yang dibutuhkan oleh pasien tersebut perlu menggunakan obat kontras atau tidak, Selain itu bisa informasikan mengenai biaya, dalam hal ini peneliti menggunakan prosedur tanpa menggunakan obat kontras, kemudian pasien diarahkan ke meja kasir untuk melakukan pembayaran pemeriksaan. Langkah selanjutnya radiographer melakukan identifikasi pasien terkait pemeriksaan yang dibutuhkan kemudian menganamnesa kepada pasien tersebut. Dalam hal ini pasien melakukan pemeriksaan MSCT Thorax - Non Contrast sesuai dengan yang dibutuhkan pasien tersebut. Setelah melakukan pemeriksaan tersebut pasien bisa mengkonfirmasi ke bagian administrasi untuk pengambilan hasil pemeriksaan tersebut.

Terkait dengan prosedur pemeriksaan radiologi pada saat protokol covid-19 dilakukan dengan satu sampel yaitu pasien atas nama bapak X berusia 52 tahun dengan gejala batuk, sesak nafas, dan indra penciuman tidak berfungsi. Pertama Pasien datang ke bagian poli ISPA yang berada di tower II Gedung rumah sakit mayapada Jakarta selatan untuk dilakukan pemeriksaan lab untuk melakukan pemeriksaan swab-pcr guna untuk memastikan pasien tersebut menderita COVID-19 atau tidak. Setelah menunggu hasil swab ternyata pasien tersebut positif COVID-19, kemudian dilanjutkan pemeriksaan penunjang lainya yaitu modalitas Computed Tomography (CT-Scan)

CT-Scan Thorax untuk memvisualisasikan gambaran thorax sebagai tahap evaluasi. Sebelum melakukan pemeriksaan di. Radiologi yang berada di tower I pasien/perawat harus melakukan appointment terlebih dahulu dan melampirkan hasil swab kepada petugas radiologi. Berikut hasil swab dan form pemeriksaan CT-Scan yang di tunjukkan pada petugas radiologi

Jam operasional pada pelayanan radiologi untuk pasien penderita Covid-19 yaitu pada pukul 13.00-15.00 WIB dan pukul 21.00-23:00 WIB. Tujuan pembagian waktu tersebut semata-mata ingin mencegah penularan Covid-19. Setelah melakukan appoiment ke petugas radiologi dengan jam yang sudah di tentukan, pasien tersebut mendapat pemeriksaan pada pukul 13.25 WIB. Setelah itu pasien melakukan pemeriksaan CT-Scan Thorax yang ada tower 1 dengan melewati akses khusus yang sudah 
disediakan dari pihak rumah sakit, setelah sudah berada di instalasi radiologi yang berada di tower 1 , pasien tersebut di arahkan oleh petugas radiologi yang sudah menggunakan APD lengkap menuju ke ruang CT-Scan untuk dilakukan pemeriksaan CT-Scan Thorax, setelah pemeriksaan selesai, pasien diinstruksikan kembali ke poli ISPA yang ada di tower 2 untuk melanjutkan instruksi dari perawat poli ISPA.

Berdasarkan hasil gambaran CT-Scan yang telah dilakukan terdapat multi focal Grand Glass Opacity $>3$ buah, dengan ukuran sebesar $>3 \mathrm{~cm}$ pada posterobasal kedua.

\section{Pembahasan}

Berdasarkan hasil penelitian di Instalasi Radiologi Rumah Sakit Mayapada dilakukan beberapa alur prosedur pemeriksaan terkait protokol Covid-19 dengan sebelum Covid terdapat perubahan yang signifikan dalam menerima atau memeriksa pasien yang datang ke unit radiologi yaitu sejalan dengan teori/panduan Kesehatan yang diterapkan oleh Kemenkes:

Alur pasien

Pasien masuk ke ruang radiologi dapat melalui IGD atau area rawat jalan proses masuknya pasien melalui radiologi dapat melalui 3 cara:

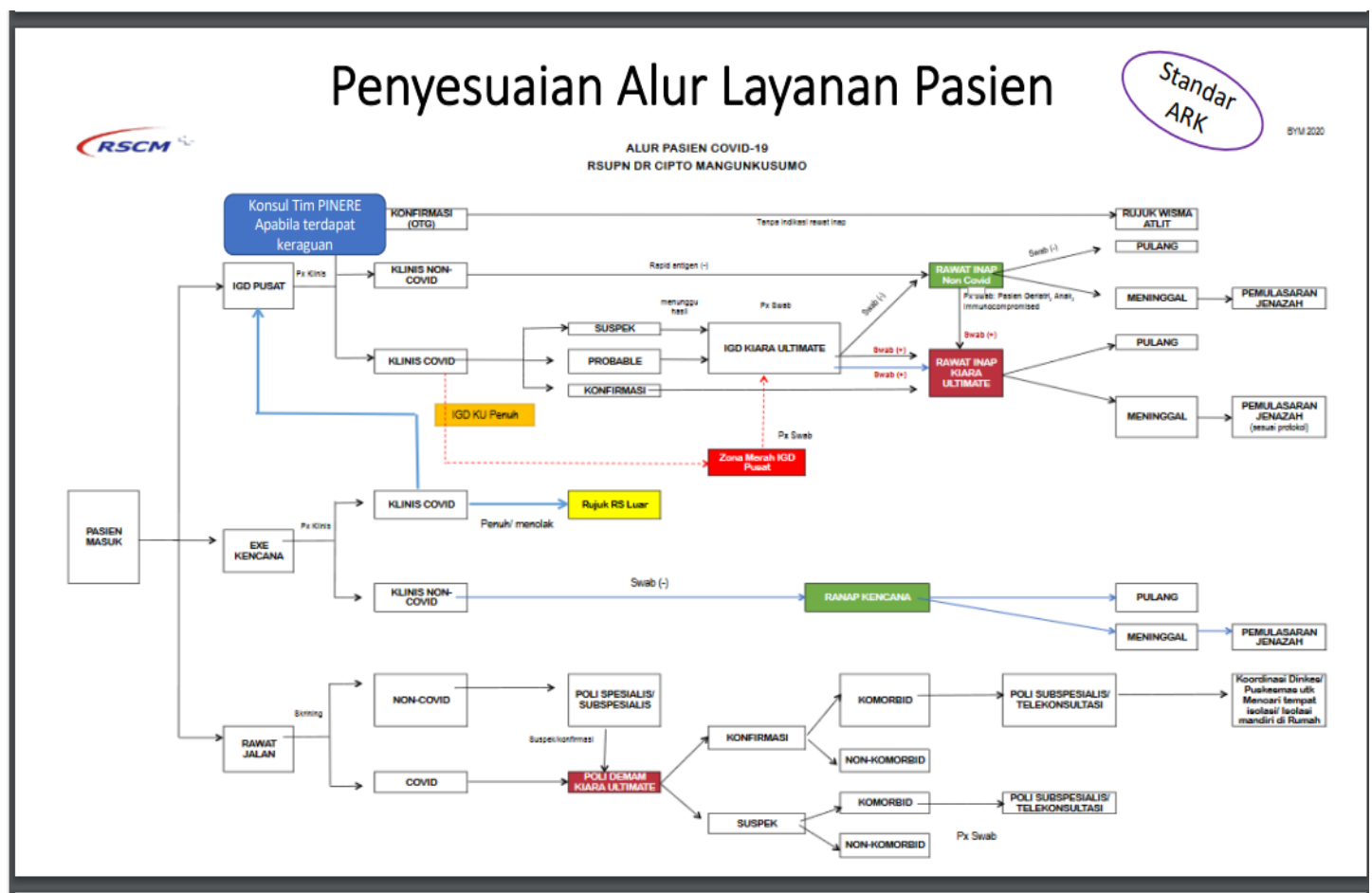

Gambar 2. Proses masuk pasien radiologi

1. Langsung ke radiologi (atas permintaan pasien sendiri dan tanpa perjanjian)

Pasien yang masuk ke radiologi ia harus melalui proses screening, bila hasil skrining dicurigai Covid-19 maka pasien diarahkan menuju triase IGD atau rawat jalan khusus Covid-19. Sebaliknya bila dari skrining tidak dicurigai Covid-19 maka pasien diarahkan ke IGD atau rawat jalan nonCovid-19 sesuai kebutuhan pasien. 
2. Melalui rujukan (dari Faskes Kesehatan Tingkat Pertama (FKTP) atau (Faskes Kesehtan Tingkat Lanjut)

\section{Skrining pada Pasien dan Pengunjung}
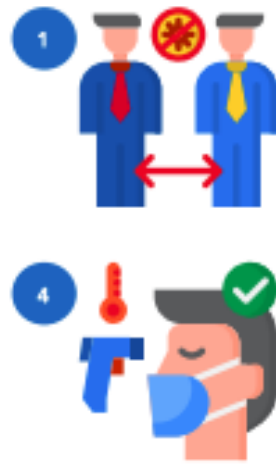
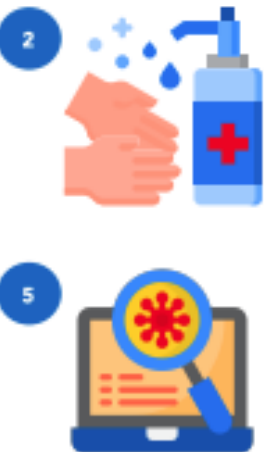

。

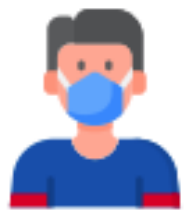

ง

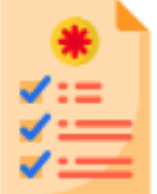

Gambar 3. Skrining pada pasien dan pengunjung

\section{Pembagian Zona Risiko Penularan Covid-19 di Radiologi}

Zonasi ruang dan waktu adalah pembagian atau pengelompokan pelayanan radiologi berdasarkan kesamaan karakteristik fungsi kegiatan dan tujuan tertentu. Pembagian zonasi tersebut dilakukan untuk mencegah penularan Covid-19 di ruang radiologi antar penderita/bergejala Covid-19 dengan non Covid-19. Zonasi radiologi berdasarkan risiko penularan Covid-19 dibagi menjadi dua yakni:

\section{Zona COVID-19}

\section{Zona Non-COVID-19}

\section{Zona Covid-19}

Merupakan area/ruangan radiologi yang tingkat risiko terjadinya penularan COVID-19 tinggi karena berhubungan secara langsung maupun tidak langsung dengan pelayanan radiologi. Zona ini diperuntukkan bagi pasien kontak erat, suspek, protable dan konfirmasi COVID-19, yang termasuk dalam zona COVID-19 meliputi instalasi radiologi yang berada di Rumah Sakit Mayapada Jakarta Selatan seperti ruangan rontgen , ruang Computed Tomography (CT-Scan), ruang Magnetic Resonance Imaging (MRI), ruang Ultrasonography (USG) 


\section{Zona Non COVID-19}

Merupakan area/ruangan radiologi yang tingkat risiko terjadinya penularan Covid-19 Rendah karena tidak berhubungan langsung langsung dengan pelayanan pasien Covid-19, yang termasuk zona tersebut meliputi Ruang Magnectic Resonance Imaging (MRI), Ruang Administrasi, Ruang Bone Mineral Densitometri (BMD).

Selain itu hasil penelitian yang penulis tulis juga sejalan dengan pedoman dan aturan yang diterapkan oleh rumah sakit Mayapada Jakarta Selatan terkait dengan prosedur pemeriksaan di instalasi/unit radiologi yang tujuannya agar pasien PDP dan Covid-19 tidak melakukan pemeriksaan di waktu yang bersamaan. Berikut prosedur pemeriksaan radiologi yang diterapkan oleh Rumah Sakit Mayapada Jakarta Selatan:

1. Ruangan rawat inap Tw.2, IGD ISPA, Poli ISPA menelepon ke bagian radiologi untuk melakukan perjanjian pasien.

2. Formulir permohonan pemeriksaan radiologi (FPPR) di scan di ruangan masing-masing dan dikirim ke email radiologi, kemudian admin atau radiographer akan melakukan penginputan ke dalam sistem.

3. Pasien dari Tw.2 baik rawat inap, rawat jalan maupun IGD ISPA akan melalui lift dalam (khusus pasien) dan akan naik ke lantai 3. Dari Tw.2 ke Lt.3 melalui sky bridge menuju radiologi tw.1 Lt.3

4. Admin dan radiographer akan menginfokan jam pelayanan pasien PDP dan Covid-19 yaitu : Sesi pertama pada jam 13:00- 16:00, dilanjutkan pada sesi kedua pada jam 21:00 -23:00, untuk pelayanan foto thorax 24 jam di ruang radiologi Tw. 2 Lt.1

5. Untuk Tindakan lain selain foto thorax dilakukan di radiologi Tw.1 Lt.3 mengikuti jam pasien Covid-19, yaitu MSCT dan USG.

6. Untuk pasien cito yang tidak bisa menunggu untuk dilakukan pada jam pelayanan pasien PDP dan Covid-19, sebelumnya Ruangan radiologi akan dikosongkan terlebih dahulu dari pasien umum, setelah steril dari pasien umum kami akan menghubungi ruangan di mana pasien cito membutuhkan pemeriksaan radiologi di Tw.1, dan Radiologi bekerja sama dengan security Lt.3 akan memasang garis pembatas (police line) berwarna kuning di sekitar radiologi sampai dengan pemeriksaan selesai.

7. Setelah Tindakan di radiologi selesai dilakukan general cleaning dan penyemprotan desinfektan oleh tim SJS.

8. Hasil diantar ke ruang perawatan oleh ajun jam 08.00-16.00 WIB. Di luar dari jam yang ditentukan bisa dilihat melalui radiologi.

Selain itu dari hasil penelitian terdapat beberapa kesamaan dari beberapa terkait penerapan alur pelayanan pasien Covid-19 yaitu:

1. Petugas skrining melakukan skrining Covid-19 di ruang skrining sebelum masuk IGD.

2. Pasien ditentukan apakah skrining covid positif atau skrining covid negatif.

3. Pasien dilakukan triage untuk menentukan level kegawatan ( biru, merah, kuning, hijau)

4. Pasien dengan skrining Covid ditempatkan di ruangan isolasi Covid IGD

5. Petugas yang mengantar ke ruang isolasi Covid IGD harus menggunakan APD level 2

6. Sedangkan pasien dengan skrining Covid negatif di tempatkan di luar isolasi Covid sesuai dengan level kegawatdaruratan pasien

7. Pasien dilakukan pemeriksaan penunjang radiologi

8. Bila pasien dengan status suspek dan indikasi rawat jalan maka dokter memberikan edukasi untuk isolasi mandiri

9. Petugas yang masuk ke ruang isolasi menggunakan dan melepas APD sesuai prosedur

10. Dokter melakukan edukasi kepada pasien dan keluarga:

a. Diagnosa medis pasien

b. Status Covid pasien (suspek atau protable) dan tata laksana selanjutnya 
c. Alur pelayanan pasien suspek atau protable covid di IGD

11. Edukasi didokumentasikan pada lembar rekam medis IGD terintegerasi

Dari beberapa standar prosedur operasional terkait alur lama dan alur model baru terdapat perbedaan yakni :

1. Jam operasional

Jam operasional pada model alur baru lebih memberikan rasa aman terhadap pasien nonCovid yang di mana tujuan mencegah penularan Covid-19.

2. Zonasi

Zonasi ruang adalah pembagian dan pengelompokan pelayanan radiologi berdasarkan kesamaan karakteristik fungsi dan kegiatan tertentu , pembagian zonasi tersebut dilakukan untuk mencegah penularan COVID-19 di ruang radiologi antar penderita/ bergejala COVID-19 dan nonCOVID-19.

3. Skrining

Terdapat signifikan terkait skrining pada alur lama dan alur lama, pada alur baru saja misalnya setiap pasien harus mengisi kuesioner, harus melampirkan hasil swab dan harus melakukan cek suhu sebelum masuk ke dalam rumah sakit.

\section{PENUTUP}

Guna untuk mencegah terjadinya penularan yang masif perlunya dilakukan pembagian zona ruang dan zona waktu dalam pelayanan kesehatan, tak terkecuali dalam pelayanan kesehatan dalam radiologi, dengan diberlakukannya dapat memberikan rasa aman dan nyaman.

Saran yang ingin penulis sampaikan terkait penelitian tersebut mengenai alur pemeriksaan radiologi di rumah sakit Mayapada Jakarta Selatan pada saat protokol Covid-19 adalah masih kurangnya alat penunjang medis dalam hal ini CT-Scan untuk sekiranya berada di tower 2 untuk memeriksa pasien khusus Covid-19 untuk meningkatkan rasa aman dan nyaman kepada pasien dan petugas radiologi.

\section{UCAPAN TERIMA KASIH}

Ucapan terima kasih kepada semua pihak yang telah membantu dalam penelitian ini terutama untuk pembimbing serta semua pihak dan seluruh responden dalam penelitian ini dan juga kepada pihak radiologi di Mayapada Hospital Jakarta Selatan sebagai tempat penelitian. Terima kasih kepada Universitas Muhammadiyah Prof. Dr. Hamka atas kesempatan yang telah diberikan dan fasilitas yang disediakan untuk dapat menyelesaikan penulisan karya ilmiah ini.

\section{DAFTAR PUSTAKA}

Baru K. (2020). Panduan teknis pelayanan rumah sakit; Alur, Pemeriksaan P. SPO RS Mayapada pada pasien covid.pdf.

Eagle S, Brassington C, Dailey C, Goretti C. (2009). The Professional Medical Assistant. Philadelphia: F.A Davis Company.

Kesehatan K. Pedoman Pencegahan dan Pengendalian Corona Virus deases (Covid-19). Kementrian Kesehat [Internet]. 2020;5:178. Available from: https://covid19.go.id/storage/app/media/Protokol/REV-05_Pedoman_P2_COVID 19_13_Juli_2020.pdf

Moeloek, RHA. (2013). SPO_Alur_Pelayanan_Pasien_Covid-19_Di_IGD_2020.pdf. Indonesia P onklogi. pelayanan kesehatan. J Chem Inf Model 53(9):1689-99. 
Salsabila N. (December, 2020). Rencana Strategis Pelayanan Kesehatan Primer Di Indonesia Selama Covid-19. Available from: https://www.researchgate.net/publication/347948909

Tracing C. WHO-2019-nCoV-cases_clusters_investigation-2020.1-eng. 2020;(March):1-4.

WHO - UNICEF. (April, 2020). Water, sanitation, hygiene and waste management for the COVID-19 virusInterim guidance April 2020:1-9.

WHO. (2020). Mask use in the context of COVID-19. Who [Internet]. (December):1-10. Available from: https://www.who.int/publications/i/item/advice-on-the-use-of-masks-in-the-communityduring-home-care-and-in-healthcare-settings-in-the-context-of-the-novel-coronavirus-(2019ncov)-outbreak

WHO. (March, 2020). Infection Prevention and Control guidance for Long-Term Care Facilities in the context of COVID-19. Retrieved march 29, 2020 From https://www.who.int. Interim Guid World Heal Organ:1-5. 